\title{
Teknosport: Communicating to Prevent Change
}

\section{Priscilla S. Rogers}

University of Michigan, Ann Arbor

A

S A REGIONAL MANAGER of Sales for TeknoSport, you oversee the selling of all TeknoSport products and services for four of the company's stores in the metropolitan area of Helsinki, Finland. Founded in 1980 in Turku, a major city in west Finland, TeknoSport is a mid-sized, highly competitive retail business specializing in sports training equipment with 19 of its own stores throughout Finland, Sweden, and Norway. In addition to offering standard brand-name products, the firm also has some special products manufactured for it under the TeknoSport label, products ranging from ski caps to electronic devices. Over the years, TeknoSport has developed a reputation for selling technologically innovative products and athletic product packages including electronic equipment, such as cardiac monitors, elestronic weights, and video-playback systems. For example, TeknoSport recently won a lucrative contract to upgrade all the athletic equipment at the Kerttula Sports Arena in Raisio near Turku, as well as to install video-playback systems for athletes and coaches to review performance. In fact, the Raisio tiedottaa (Raisio Informs), a city paper distributed free to every household in Raisio, published a feature story on this effort. It had a photograph of Olympic Gold medalist, Mr. Pertti Karppinen, and one of TeknoSport's new hires, Mrs. Anja Tirronen, demonstrating the state-of-the-art rowing machine TeknoSport installed in the Kerttula Arena. The article compared Mr. Karppinen's rowing ability with Mrs. Tirronen's extensive knowledge about the rowing equipment.

\section{TeknoSport's Sales Training Program (STP)}

Since 1986, new hires for TeknoSport's sales staff have been required to complete a rigorous, five-day Sales Training Program (STP). 
Although TeknoSport hires sales personnel with excellent athletic backgrounds, including both practical experience and education in athletics, few are familiar with all the different sports the company caters to. Moreover, new sales personnel have much to learn about selling the equipment, establishing and maintaining customer contacts, using the firm's complex communication system, and fitting in with the company's culture, all of which are covered in the STP. TeknoSport's STP is designed to train new sales personnel in specialized skills for demonstrating products (often requiring quite technical knowledge), helping customers to select the products best suited to their needs, and teaching customers to use the equipment they purchase. In the STP, sales staff also learn methods for using the company's communications system and the Internet for researching products, health-related issues, new developments in the athletic equipment industry, as well as for accessing customer data and reporting sales information.

Based on your company knowledge and sales experience, you believe that much of TeknoSport's sales growth can be attributed directly to the STP. The year after STP was implemented, new employees' sales on average rose 10 percent over the cohort from the previous year, and the new hires in subsequent years have improved on that figure some every year. In fact, despite increasing competition from several firms, the annual sales for all TeknoSport's employees have averaged 15 percent above the industry average since STP was originated.

\section{STP Opened to Long-time Sales Personnel}

While the STP was originally designed to train new hires, in 1992 some of the sessions were redesigned and opened to long-time sales personnel. This decision was based on two key factors. As the product base expanded and sales staff had to do more research on individual client's needs, long-time staff benefited from those parts of the sales training program devoted to new products. In addition, TeknoSport's new communications system was continually being updated (allowing individual salespersons to handle more customers, for example), so old hands needed communications training too. Since all the longtime sales personnel needed periodic retraining to learn about the new products and the modifications to the communications system, 
the redesigned STP sessions for experienced employees became a regular feature. In fact, one STP session was developed as a forum in which new and old sales personnel could share information on customers and sales strategies, as well as brainstorm about potential new product packages.

Currently, the STP is offered at TeknoSport headquarters in Turku each quarter to both new and experienced sales personnel. Five days of STP classes are mandatory for new hires. On a voluntary basis, veteran employees may attend two days of one STP offering each year, specifically those days focusing on new products, package design, and communications. Since the redesign of STP was completed in 1992 to meet the needs of both new and experienced sales personnel, the seminar-size classes have been fully enrolled, with long-time employees typically waiting a year to get into the Program because of its popularity. Participant survey evaluations (on a 5-point scale) increased from an average rating of 3.8 for the old program to 4.7 for the redesigned STP. Sales personnel, both old and new, regularly praise the STP, saying that it provides information about new products that improves their ability to sell better than their competitors. Long-time salespersons' comments on the survey claim that they believe the STP sessions help them integrate new products, create innovative product packages that are unique to TeknoSport, and manage their workloads more efficiently by fully using TeknoSport's communications capabilities. New hires report that the STP builds their confidence, fosters team spirit, and helps them feel they are an important part of TeknoSport.

\section{Proposal to Eliminate the STP}

At your meeting earlier this week of the regional sales managers, TeknoSport's new president, Harri Karvinen, came to make a couple announcements. First, the company still had not found the right person to be Vice President for Marketing \& Sales (replacing a long-time employee who left to take a position in a British firm), so he would continue to act in that key position. Second, he and the Board were dedicated "to cut the fat out of TeknoSport, to make the company leaner." Speaking bluntly, Karvinen said, "We currently need to focus our resources on new product development and on improving our 
communications technology. To compete effectively, we plan to eliminate non-essential programs, like STP."

When you questioned the proposal to drop STP, Karvinen continued: "Sales techniques can be learned through immediate and direct experience with products and customers. An apprenticeship system in which new sales personnel work side-by-side with experienced hands would work well, as it does in many Finnish companies, especially now that we have less turnover and more seasoned sales personnel. Communications systems can also be learned on the job, particularly if we put money into improving and simplifying them. After some deliberation, the Board and I favor a buddy system, linking experienced and new employees and utilizing some of the quiet time in the stores. Also, I think it might be cheaper and smarter if we sent some of our most experienced sales personnel to professional training programs. They could then do an even more effective job of one-on-one training with the new hires." Karvinen paused and then said: "At a certain point, there's no more we can learn from ourselves, and we need to spend our training dollars on getting new knowledge. Besides, the STP cannot substitute for real experience with customers under the guidance of seasoned sales personnel."

Karvinen wasn't done yet. "This kind of company classroom training is certainly not essential," he said. "I believe that current sales personnel can provide effective on-the-job training for new hires at least as effectively as the STP. Moreover, using an apprenticeship system instead of the STP would allow us more resources for technological developments, both for our product line and communications system. We have to remember that the cost of the STP is not only in Finn marks spent on the program, but also in time and in potential sales that are lost every time STP is offered. When seasoned sales personnel attend the STP, they're not selling, and neither are the three STP trainers, two of whom started the program and all of whom are among TeknoSport's best salespeople."

\section{Response to Karvinen's Plan}

You and other regional sales managers all expressed your concerns about the pending decision to drop the STP, especially without a full airing of views. You reminded Karvinen that return customers account for over 65 percent of TeknoSport's sales and that market sur- 
veys show that customers rank knowledgeable sales people as their number one reason for buying from TeknoSport rather than from a competitor. You also explained how the STP is really helping longtime sales personnel to become fully knowledgeable about the new products and the new communications systems, something they never had adequate time to do when training was only for new hires.

Karvinen responded, "Resource redistribution is always difficult. Of course we don't want to cut any programs, but change is necessary. I understand that the STP has been good for TeknoSport in the past when we had so much turnover in the sales staff, but to be competitive in the future, we must commit more resources to technological developments for new product packages, as well as further improvements in our communications system. If we're going to consider keeping STP now that most of our sales personnel are highly experienced," he continued, "we need some very substantial reasons for doing so. Everyone on the Board agrees that this redistribution of our resources is best for TeknoSport right now. If there's something vital about the STP we've not taken into account, you need to let us know right away," he concluded.

Although Karvinen had been with TeknoSport for only about three years before being elevated to president, he is respected by all the regional sales managers for his knowledge of the sports training business, experience in sales, and background in physical fitness training. Karvinen's promotion last month was part of a company-wide effort to help TeknoSport become even more competitive. Although he had never said much about STP, his plan to eliminate the training program took you and the other regional sales managers by surprise. You had simply assumed that he, seemingly like everyone else at TeknoSport, would consider the STP to be at the heart of TeknoSport's continued success. 


\section{Assignments}

In preparing all the assignments except the final one, assume the role of a regional sales manager at TeknoSport. For Assignment 5, assume the role of a sales employee.

\section{Assignment 1: Communication Strategy}

Meet with the other regional sales managers at TeknoSport. Develop a consensual plan on how to advance your views about STP, a plan including whom to contact, for what reason(s), via what communication media. Determine your overall objective and then articulate a specific purpose for each communication you propose, making sure that each communication complements the others.

\section{Assignment 2: Persuasive Memo}

Assuming the role of the Regional Sales Manager for Helsinki, write a memo to Harri Karvinen on behalf of all of the regional managers to accomplish your objectives about STP. Assume that he will distribute the memo to TeknoSport's Board. Use details from the case to support your claims. You can also draw inferences from the data based on your own knowledge of business and of training programs, but do not make up any information.

\section{Assignment 3: E-mail Request}

Assuming the role of the Regional Sales Manager for Helsinki, prepare an e-mail attempting to persuade Harri Karvinen that in the absence of a Vice President for Sales and Marketing, he should allow either a representative of the group of regional sales managers or the entire group to address the Board of Directors about the STP.

\section{Assignment 4: Formal Persuasive Presentation}

Assume that Harri Karvinen says yes to your e-mail request. Prepare either an individual or a team presentation (with visual aids) to persuade the Board of Directors to accept your objectives for the STP. Use details from the case as support for your arguments for the STP. You can also draw inferences from the data and, if you wish, use your own knowledge of business and of training programs, but do not make up any information. 


\section{Assignment 5: Persuasive E-mail Message}

Assume that you are a sales employee at TeknoSport Store 2 in the Helsinki area. Lately there have been rumors that the STP may be ter- , minated as part of the new CEO's plan to cut costs and make the company more competitive. After discussing the rumors with the manager of your store, you and some of the other sales associates decide to write an e-mail in support of retaining the STP to President Harri Karvinen in Turku. Develop a consensual plan with your group and prepare an e-mail message that advocates your group's position on STP.The e-mail should be addressed to h.karvinen@tekno.fi. 